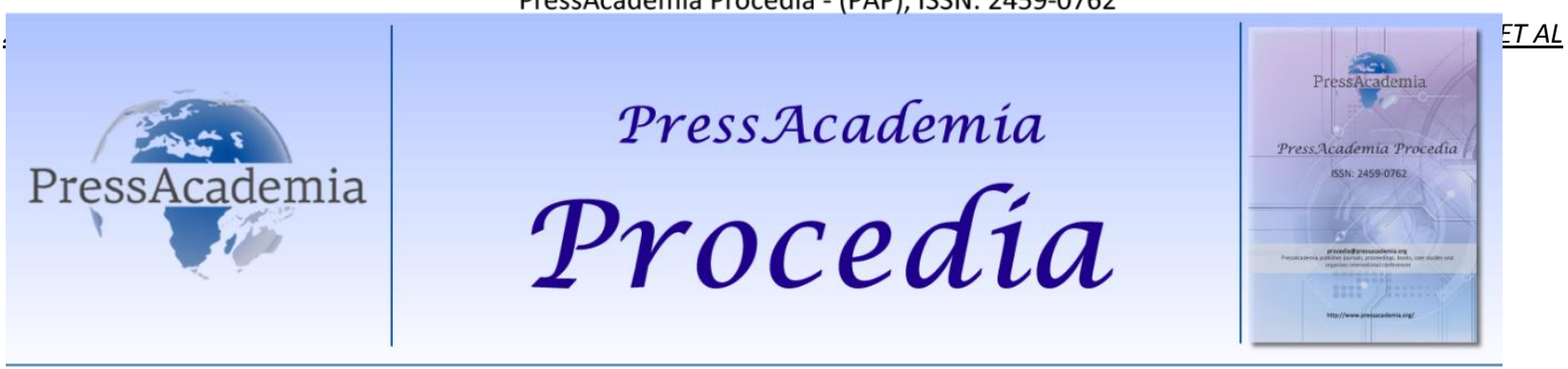

2nd World Conference on Technology, Innovation and Entrepreneurship

May 12-14, 2017, Istanbul, Turkey. Edited by Sefer Şener

\title{
A RESEARCH ABOUT THE EFFECT OF THE STRATEGICAL FINANCIAL PLANNING OF THE COMPANIES IN LOGISTICS SECTOR IN TURKEY ON THE COMPANY GROWTH
}

\section{DOI: 10.17261/Pressacademia.2017.525 \\ PAP-WCTIE-V.4-2017(17)-p.114-122}

\author{
Mustafa Yurttadur ${ }^{1}$, Alp Simsek ${ }^{2}$, Muammer Unlu ${ }^{3}$, Serhan Cihan ${ }^{4}$, Seyma Araci $^{5}$ \\ ${ }^{1}$ Istanbul Gelisim University, Faculty of Economics, Administrative and Social Sciences, myurttadur@gelisim.edu.tr \\ ${ }^{2}$ Istanbul Gelisim University, Institute of Social Sciences, alpsimsek34@gmail.com \\ ${ }^{3}$ Istanbul Gelisim University, Institute of Social Sciences, muammer.unlu@und.org.tr \\ ${ }^{4}$ Istanbul Gelisim University, Institute of Social Sciences, serhan_cihan 58@hotmail.com \\ ${ }^{5}$ Istanbul Gelisim University, Institute of Social Sciences, araciseyma80@gmail.com
}

\section{ABSTRACT}

The financial planning involves a part of the planning process, and the planning helps to improve the profit, develop the decision making and even decrease the number of it. The planning means to take the decisions which will affect the future of the company by today. Since the future is indefinite, it is also possible that the plans made are not realized. That's why the future is a moving target, and the reason of the planning is to achieve the goal of the company. Logistics enterprises that actualize the financial planning effectively can grow with ease. Because all the sources obtained are used most effectively, and these actually used sources affect the company growth positively. Revealing how the strategical financial planning of the enterprises in the logistics sector in Turkey should be and how these financial plans affect the company growth are the primary purposes of this study. For achieving this purpose, the relations between literature and the terms are tried to be supported by the major studies after being described the conditions that generate the content of the survey. The hypothesizes of the research has begun to be developed by being created the theoretical framework. Within this scope, firstly a research was actualized by a questionnaire form to see at what level the strategical financial planning in companies grows in comparison with the profitability of the company, company growth, and the sector average. The data obtained were evaluated by the statistical analysis then tested by the hypothesis as well.It is observed at the end of the analysis that the strategical financial planning is essential to empower the financing structure of the companies in the logistics sector and being realized this planning correctly is directly associated with the correct financial decisions
\end{abstract}

Keywords: Financial planning, strategical financial planning, financial profitability, company growth, logistics sector JEL Codes: G10; G32

\section{INTRODUCTION}

Financial planning is the issue that how the company will achieve its strategical targets earthily. A company generally creates the financial planning after being specified the vision and the purposes. The financial plan defines each information, source equipment and the material and the time zone for all these to achieve the goals. The strategy includes the competitive moves, internal business approaches and the plans of actions of the company established by the management to be successful. It is the 'Game Plan' required to carry on the business. The administrators need for the strategies that will guide for achieving the targets and managing the institution.

The strategical financial management is being planned the use of the financial sources and management for providing to reach the goals as a commercial enterprise and values for the shareholders. The strategical financial planning completely includes describing the business targets of the company, determining and measuring the sources, planning to benefit from pecuniary and other sources, establishing methods to analyze and collect the data, taking financial decisions, analyzing and following the paradox between the real results and the budget, then operating in corrective actions to specify the problems. Much as being emphasized on how the innovation is necessary at present, it is not dwelled on how this can be actualized as active and productive (Uzkurt, 2010). 


\section{FINANCIAL INNOVATION}

Innovation comes from the word 'innovatus' in Latin. Its lexical meaning is to change, renew, reveal new and submit. The innovation emerges as a process includes being turned the new ideas, new markets, and the applications into the new goods and services, adopted, applied and coalesced (Akın, Reyhanoğlu, 2014).

The first studies about the innovation start with Hyman Minsky at the beginning of the 1950s. The companies firstly need to have an organization culture encourages the innovation to conduct their activities successfully. The businesses that have an innovational culture need to synchronize their innovation strategies with their organizational structure and provide for the process in the sense of managerial. Besides, the research and development structure of the company must be strong, and the financial support for this field must be provided for being conducted the activities of innovation. One of the required subjects to increase the effectiveness on this issue is the fundamental situation of the competition. Thus, the time of getting into the market of a new product is a pretty important case for the success. Moreover, the price and quality performance of the product developed must be confirmed with the competitive structure of the market operated in (Işık, 2011).

\section{STRATEGICAL PLANNING IN COMPANIES}

The strategy is the process of setting goals, planning the actions and reorganizing the required instrument and sources by the business to govern itself and provide a competitive advantage (Dinçer, 2007).

The way of obtaining competitive advantage and making it permanent is only the strategical management, not to have a strategy (Erol et al., 2013). The strategical planning is an institutional management activity used to determine the priorities, focus the energy and sources, strengthen the operations, provide employees and other stakeholders to work in the direction of the shared goals, agree upon the results purposed and evaluate and arrange the direction of the organization. It is a disciplined effort creates the necessary decisions, and the actions shape the organization by focusing on the future by asking what the organization, who does it serve for, what and why it does by an emphasis on the future. A valid strategical planning also means how the company will know if it is successful or not beside creating the actions for making progress.

\subsection{Planning}

The plan shows the itinerary and course of action to be successful. The planning is thought as a process helps a manager to look ahead and find the choices open for himself/herself. The planning can be defined in 2 ways as in the strict sense and broad terms. The planning in broad terms can be defined as process show the way to follow for achieving a goal under the light of current data and possible developments in the future. The planning in the strict sense is the 'process that predetermines what will be done by who and where and when.'

The planning is the crucial function create the first stage of the management process. The success of other management functions depends on a proper planning above all. Reaching the companies to a more complex structure by growing gradually, rapidly changing the dynamic market structure, fierce competition environment, ever-changing economic conditions and advanced technology increase the importance of planning nowadays.

\subsection{Strategical Management and Strategical Planning}

The strategical management argues that there is a need for the organizations can control the ever-changing environment and comply with this changing. The strategical management sets the target for the operational environment of the company. It must be occurred by planned and conscious methods beyond setting a goal in a reactional sense. Much as the strategical management is known with its widely decision mechanism and planning methods at present, the sociological approaches to this subject have started to gain importance lately ( Aktan, 1999).

The strategical management process involves the required research, review, evaluate and choosing studies to be planned, being brought all kinds of precautions into force within the company to apply these strategies, and the activities about evaluating the studies by being controlled in the next phase (Otlu and Demir, 2005). In the management science, the strategies to follow by the firms and the companies against their competitors caused to born a discipline firstly called 'strategical planning' then 'strategical management'. It needs to know the difference of strategical planing and the strategical management. While being created strategies to achieve the goals of a company, a planning of these strategies done firstly, then these procedures are conducted. The results of implementations are reviewed and controlled in the final stage. The plans are prepared for a particular period so as to be short, medium and long termed. The short term projects include less than or up to 1 year; medium termed plans include 1-5 years time, and the long termed programs mostly include10-15 years time. It is accepted in the studies about strategical management that the big businesses have more knowledge on process, instruments, method and activities of strategical management and the strategy formulation process is more extensive in these companies (Sucu, 2010). 
The globalization makes its presence effectively in economic, political, social, cultural and technological fields. Within this scope, the ones with the greatest increase in mobility are the circulation of money, labor, and the goods.(Şener, 2009) A successful planning depends on the knowledge, experience, intelligence level and the prediction abilities for the future in advance of the people prepare the plan. The biggest challenge in planning activity is to predict the future in advance incisively. The success in planning depends on the exact estimations. On the other hand, it must not be forgotten that making an exact prediction is a pretty difficult act. Being faced with some 'uncertainty' and 'risk factors' are two of the fundamental reasons complicate to predict. Some of the factors cause to the uncertainty are; technological developments in future, fashion, seasonal and economical structural changes. The directors of the companies may take several precautions to destroy the effects of the uncertainty factors or at least to minimize them. The existence of a proper accounting and budgeting system and being used the good statistical data help for evaluating the available conditions and predicting the uncertainties in the future. Various estimation methods, notably the statistical ones are used to predict. When the time covered by the plans becomes shorter, the success of estimating methods increases.

\subsection{Strategical Financial Planning}

The financial planning is a part of the planning process of the company. The planing can be useful for being increased the profit, improved the decision making and reduce the number of errors. Plan means that being taken the decisions will affect the future of the company as of today. Since the future is uncertain, it is also possible that the plans made are not realized. That's why the future is a mobile target, and the reason for the planning is being improved the purpose of the company. Financial planning means that being programmed of all kinds of fund entrance and exit in advance. Preparing the cash and the capital budgets, arranging the pro forma balance sheet, income, and resource of pro forma statements remain one of the most missions of the finance manager about the financial planning (Akın, 2015).Due to all activities of companies are prudential, the finance director has to specify the policies for future and review the policies determined before. Thus, it is tried to forecast the effects of future developments in the company. Otherwise, the possibility of not to being solved the problems increases besides not to being ideally used the existed resources. The expected thing from the financial planning is to seek a solution for cash outflows and the overplus of the money. Furthermore, the studies of being created the optimal liquidity are the goals of the financial planning. In other respects, there are a necessity for financial planning for also long termed activities besides short termed ones. But, there is especially focused on the short termed financial planning in practice.

\section{RESEARCH}

\subsection{The Theoretic Framework and Hypotheses of the Research}

\section{Variables of the Research}

Dependent Variables: Profitability of the company - Company Growth - At what level the company grows as against the sector average.

Independent Variable: Strategical Financial Planning.

Mediator Variable: Financial Decisions.

\section{Hypotheses}

$\mathrm{H}_{1}$ : There is a significant and positive relation between strategical financial planning and the profitability of the company.

$\mathrm{H}_{2}$ : There is a significant and positive relation between strategical financial planning and the company growth.

$\mathrm{H}_{3}$ : There is a significant and positive relationship between strategical financial planning and at what level the company grows as against the sector average.

$\mathrm{H}_{4}$ : Being done the strategical financial planning correctly has an important mediator variable role with being the financial decisions right. 
Figure 1: Theoretic Framework of the Research

Strategical Financial Planning

\subsection{Purpose of the Research}

It is aimed to search the effect of the strategical planning of companies in the logistics sector in Turkey on their company growth. The survey created to that end analyzed how the companies provide financial growing.

\subsection{Sampling Process}

The convenience sampling method is used in the research. Our survey was sent to 221 logistics businesses in Turkey, and 157 of them made a comeback via the internet.

\subsection{The Analysis of the Data Obtained from the Research}

The information obtained from the surveys were recorded in a computer environment, and the data file was created. Then, these data were analyzed by being transferred into the SPSS 22.0 program. Cronbach's Alpha test, Chi-Square test were conducted in the analyses; Frequency, percentage values, and the graphic data were determined.

Table 1:Cronbach's Alpha Testi

\begin{tabular}{|c|c|}
\hline Cronbach's Alpha & N of Items \\
\hline, 902 & 27 \\
\hline
\end{tabular}

The reliability of the questions prepared for analyzing the effect of the strategical financial planning of the logistics companies on the economic growth is determined by being applied the Cronbach's Alpha test. As is seen in Table 1, the number of 0,902 is calculated as 'Perfect' ( $a \geq 0,9=$ Perfect) based on the measurement criteria of Cronbach's Alpha test.

Table 2: Chi-Square Tests- The financial planning is regularized in our company* Our profitability increased by the financial planning.

\begin{tabular}{lccc}
\hline & Value & df & Asymp. Sig. (2-sided) \\
\hline Pearson Chi-Square & $7,845(a)$ & 2 &, 020 \\
Likelihood Ratio & 12,461 & 2 &, 002 \\
Linear-by-Linear & 4,367 & 1 &, 037 \\
Association & 157 & & \\
\hline N of Valid Cases & 157 & \\
\hline
\end{tabular}

a 1 cells $(16,7 \%)$ have expected count less than 5 . The minimum expected count is 4,89 .

According to Table 2, determined that the significance value is less than $0,020<0,005$ when being analyzed if there is a relation between the variables or not in the distribution of propositions called 'the financial planning is regularized in our company' and 'our profitability increased by the financial planning.' In this case, the hypothesis called ' $\mathrm{H} 1$ : there is a significant and positive relation between strategical financial planning and the profitability of the company' is accepted.

Table 3: The financial planning is regularized in our company.

\begin{tabular}{clcccc}
\hline & & Frequency & Percent & Valid Percent & Cumulative Percent \\
\hline \multirow{2}{*}{ Valid } & Absolutely Agree & 109 & 69,4 & 69,4 & 69,4 \\
& Agree & 48 & 30,6 & 30,6 & 100,0 \\
\hline \multicolumn{2}{c}{ Total } & 157 & 100,0 & 100,0 & \\
\hline
\end{tabular}


According to Table 3, all the attendees reached to the ratio of $100 \%$ by answering as 'absolutely agree' and 'agree' for the question called 'the financial planning is regularized in our company,' $109(69,4 \%)$ of them mentioned as 'absolutely agree,' and $48(30,6 \%)$ of them answered as 'agree.'

\section{Graphic 1: The financial planning is regularized in our company.}

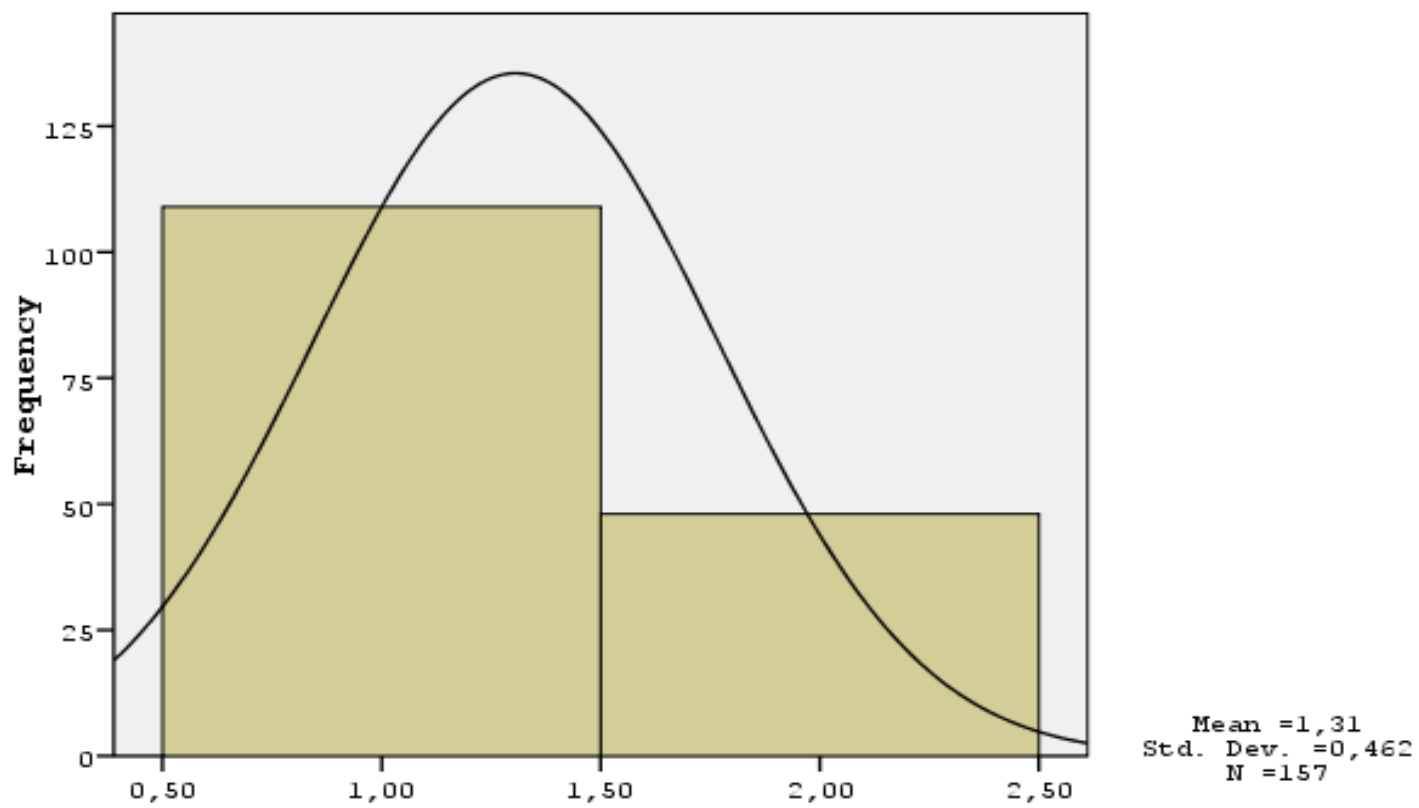

Table 4: Our profitability increased by the financial planning.

\begin{tabular}{llcccc}
\hline & Frequency & Percent & Valid Percent & Cumulative Percent \\
\hline \multirow{2}{*}{ Valid } & Absolutely Agree & 94 & 59,9 & 59,9 & 59,9 \\
& Agree & 47 & 29,9 & 29,9 & 89,8 \\
& Maybe & 16 & 10,2 & 10,2 & 100,0 \\
\hline & Total & 157 & 100,0 & 100,0 &
\end{tabular}

According to Table 4, much as $16(10,2 \%)$ people answered as 'maybe' for the question called 'our profitability increased by the financial planning,' 141 of the attendees made a positive comeback. $94(59,9 \%)$ of them answered this question as 'absolutely agree' and $47(29,9 \%)$ of them answered as 'agree.'

Graphic 2: Our profitability increased by the financial planning.

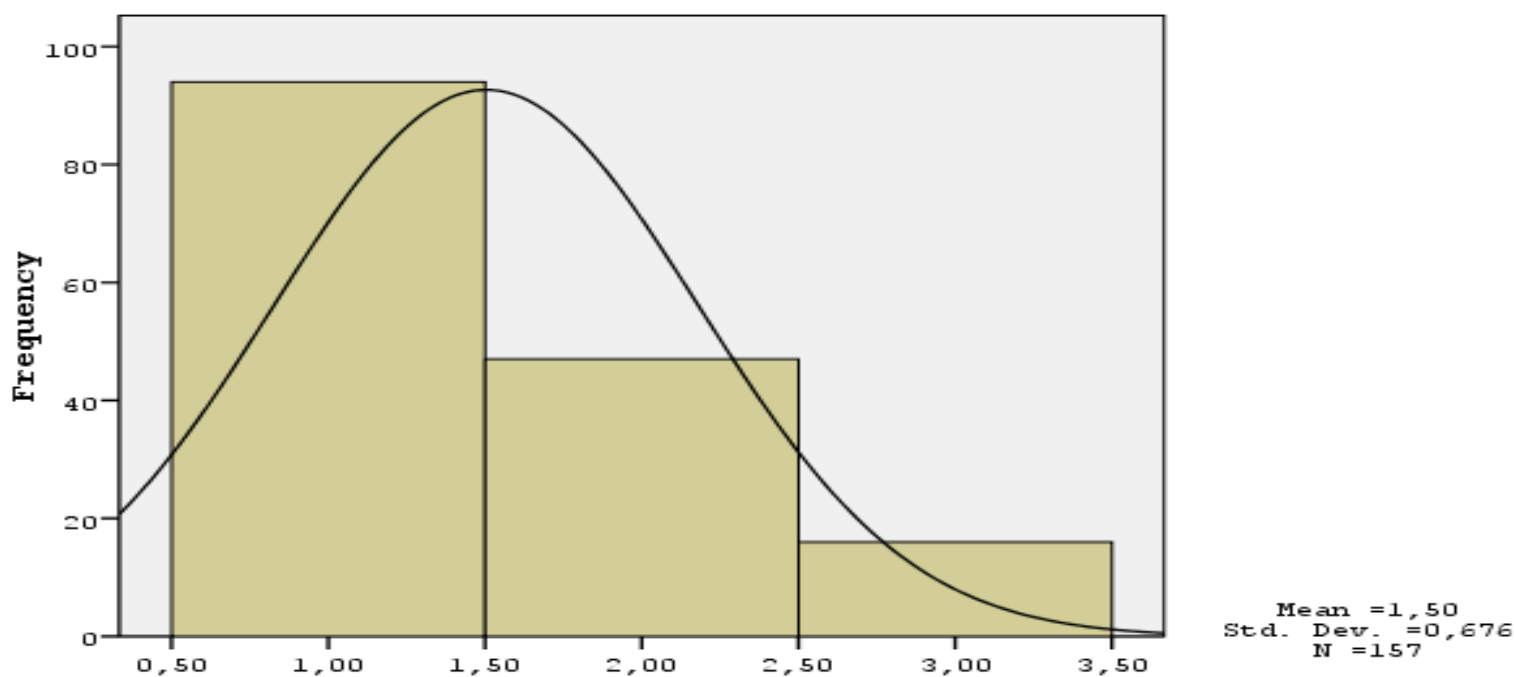


Table 5: Chi-Square Tests- The financial planning is regularized in our company.* Our company grows by the strategical financial planning

\begin{tabular}{lccc}
\hline & Value & df & Asymp. Sig. (2-sided) \\
\hline Pearson Chi-Square & $12,811(\mathrm{a})$ & 2 &, 002 \\
Likelihood Ratio & 16,990 & 2 &, 000 \\
Linear-by-Linear &, 852 & 1 &, 356 \\
Association & 157 & & \\
\hline N of Valid Cases & & \\
\hline
\end{tabular}

a 1 cells $(16,7 \%)$ have expected count less than 5 . The minimum expected count is 4,89 .

According to Table 5, determined that the significance value is less than $0,002<0,005$ when being analyzed if there is a relation between the variables or not in the distribution of propositions called 'the financial planning is regularized in our company' and 'our company grows by the strategical financial planning'. In this case, the hypothesis called ' $\mathrm{H} 2$ : there is a significant and positive relation between strategical financial planning and the company growth' is accepted.

Table 6: Our company grows by the strategical financial planning

\begin{tabular}{llcccc}
\hline & & Frequency & Percent & Valid Percent & Cumulative Percent \\
\hline \multirow{2}{*}{ Valid } & Absolutely Agree & 109 & 69,4 & 69,4 & 69,4 \\
& Agree & 32 & 20,4 & 20,4 & 89,8 \\
& Maybe & 16 & 10,2 & 10,2 & 100,0 \\
\hline Total & 157 & 100,0 & 100,0 & \\
\hline
\end{tabular}

As is seen in Table 6, the question called 'our company develops by the strategical financial planning' is confirmed by 141 of attendees. $109(69,4 \%)$ of them answered as 'absolutely agree,' $32(20,4 \%)$ of them answered as 'agree' and finally 16 $(10,2 \%)$ of them responded as 'maybe.'

Graphic 3: Our Company grows by the strategical financial planning.

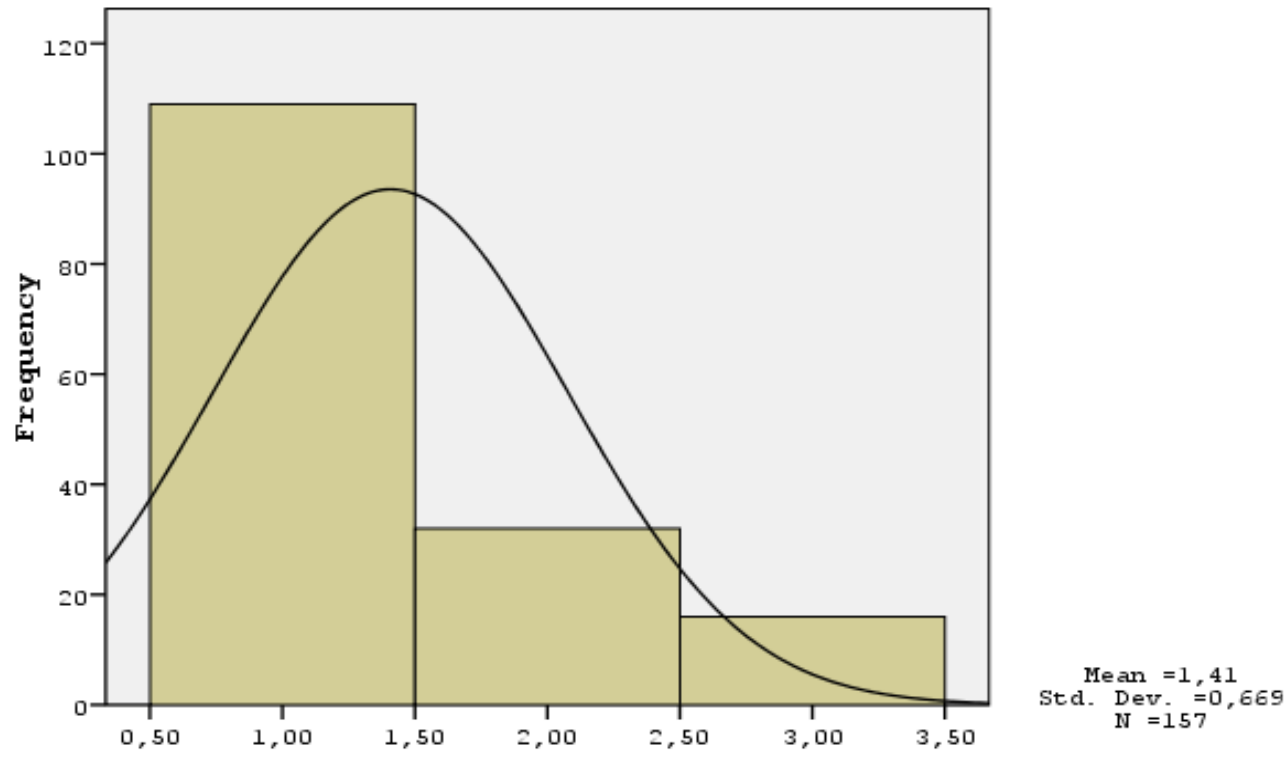

Table 7: Chi-Square Tests- The financial planning is regularized in our company*Our company grows more than the ratio of sector average by the application of strategical financial planning

\begin{tabular}{lccc}
\hline & Value & df & Asymp. Sig. (2-sided) \\
\hline Pearson Chi-Square & $43,931(a)$ & 2 &, 000 \\
Likelihood Ratio & 60,228 & 2 &, 000 \\
\hline
\end{tabular}




\begin{tabular}{lccc}
\hline $\begin{array}{l}\text { Linear-by-Linear } \\
\text { Association }\end{array}$ & 36,517 & 1 & 000 \\
\hline $\mathrm{N}$ of Valid Cases & 157 & \\
\hline a 1 cells $(16,7 \%)$ have expected count less than 5 . The minimum expected count is 4,59.
\end{tabular}

According to Table 7, determined that the significance value is less than $0,000<0,005$ when being analyzed if there is a relation between the variables or not in the distribution of propositions called 'the financial planning is regularized in our company' and 'our company grows more than the ratio of sector average by the application of strategical financial planning' . In this case, the hypothesis called ' $\mathrm{H} 3$ : there is a significant and positive relation between strategical financial planning and at what level the company grows as against the sector average' is accepted.

Table 8: Our company grows more than the ratio of sector average by the application of strategical financial planning

\begin{tabular}{llcccc}
\hline \multirow{2}{*}{ Valid } & Frequency & Percent & Valid Percent & Cumulative Percent \\
\cline { 3 - 6 } & Absolutely Agree & 96 & 61,1 & 61,1 & 61,1 \\
& Agree & 46 & 29,3 & 29,3 & 90,4 \\
& Maybe & 15 & 9,6 & 9,6 & 100,0 \\
\cline { 2 - 5 } & Total & 157 & 100,0 & 100,0 & \\
\hline
\end{tabular}

As is seen in Table 8, the answers of the attendees for the question show that the strategical financial planning is applied to the company growth and being provided a growth more than the ratio of sector average. 96 $(61,1 \%)$ of them absolutely agrees, $46(29,3 \%)$ of them agrees, and finally, $15(9,6 \%)$ of them answered as 'maybe.'

Graphic 4: Our company grows more than the ratio of sector average by the application of strategical financial planning

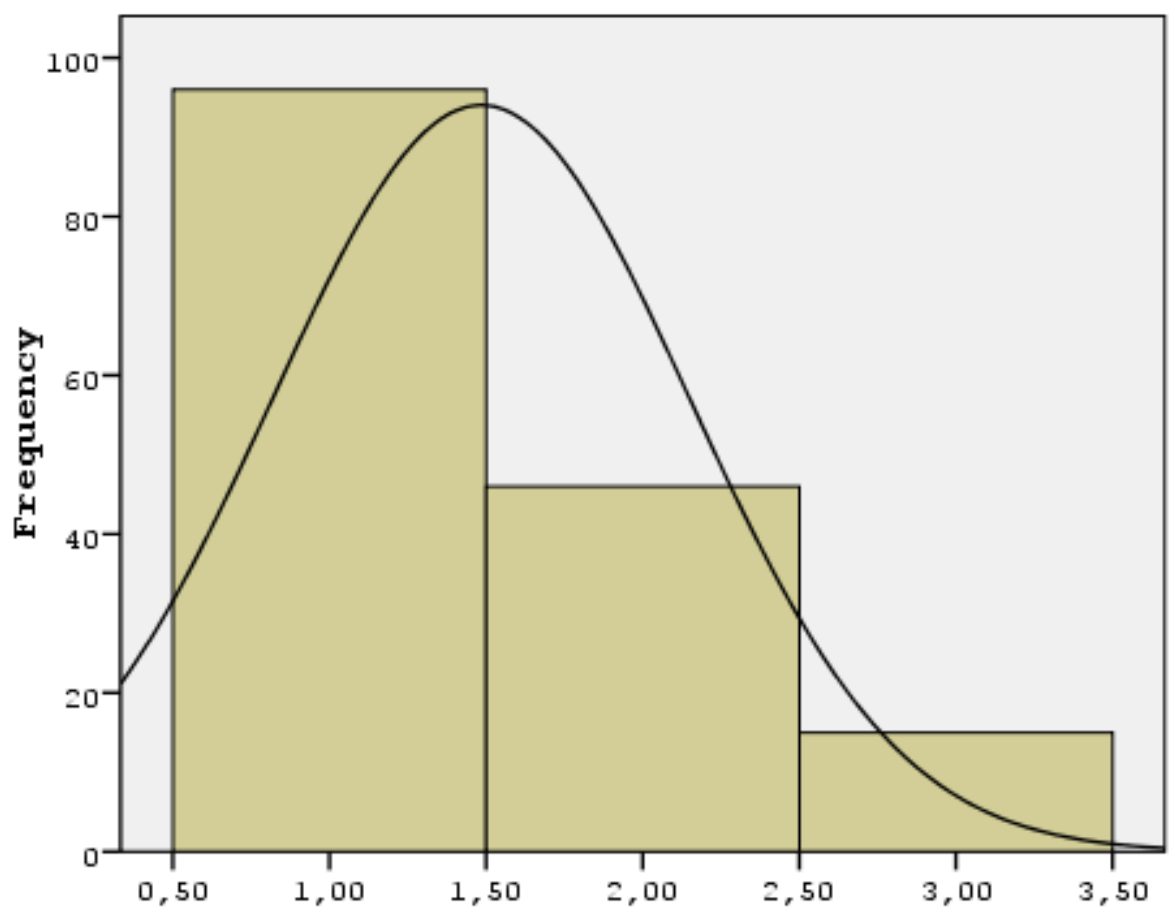

Mean $=1,48$

Std. Dev. $=0,666$

$\mathrm{N}=157$ 
Table 9: Chi-Square Tests- The financial planning is regularized in our business* The logistics companies that decide about which the strategical financial planning will apply alternative grows faster.

\begin{tabular}{lccc}
\hline & Value & df & Asymp. Sig. (2-sided) \\
\hline Pearson Chi-Square & $10,594(a)$ & 2 &, 005 \\
Likelihood Ratio & 14,335 & 2 &, 001 \\
Linear-by-Linear &, 624 & 1 &, 430 \\
Association & 157 & & \\
\hline N of Valid Cases & & & \\
\hline a 1 cells $(16,7 \%)$ have expected count less than 5. The minimum expected count is 4,28.
\end{tabular}

According to Table 9, determined that the significance value is less than $0,005<0,005$ when being analyzed if there is a relation between the variables or not in the distribution of propositions called 'the financial planning is regularized in our company' and 'the logistics companies that decide about which alternative will be applied by the strategical financial planing grows faster.' In this case, the hypothesis called 'H4: being done the strategical financial planning correctly has a significant mediator variable role with being the financial decisions right' is accepted

Table 10: The logistics companies that decide about which the strategical financial planning will apply alternative grows faster.

\begin{tabular}{llcccc}
\hline & & Frequency & Percent & Valid Percent & Cumulative Percent \\
\hline \multirow{2}{*}{ Valid } & Absolutely Agree & 109 & 69,4 & 69,4 & 69,4 \\
& Agree & 34 & 21,7 & 21,7 & 91,1 \\
& Maybe & 14 & 8,9 & 8,9 & 100,0 \\
\hline \multicolumn{2}{c}{ Total } & 157 & 100,0 & 100,0 & \\
\hline
\end{tabular}

As is seen in Table 10, the frequency distribution of the answers for the question called 'the logistics companies that decide about which alternative will be applied by the strategical financial planning grows faster' as follows; $109(69,4 \%)$ of them absolutely agrees, $34(21,7 \%)$ of them agrees, and finally $14(8,9 \%)$ of them responded as 'maybe'.

Graphic 5: The logistics companies that decide about which alternative will be applied by the strategical financial planning grows faster

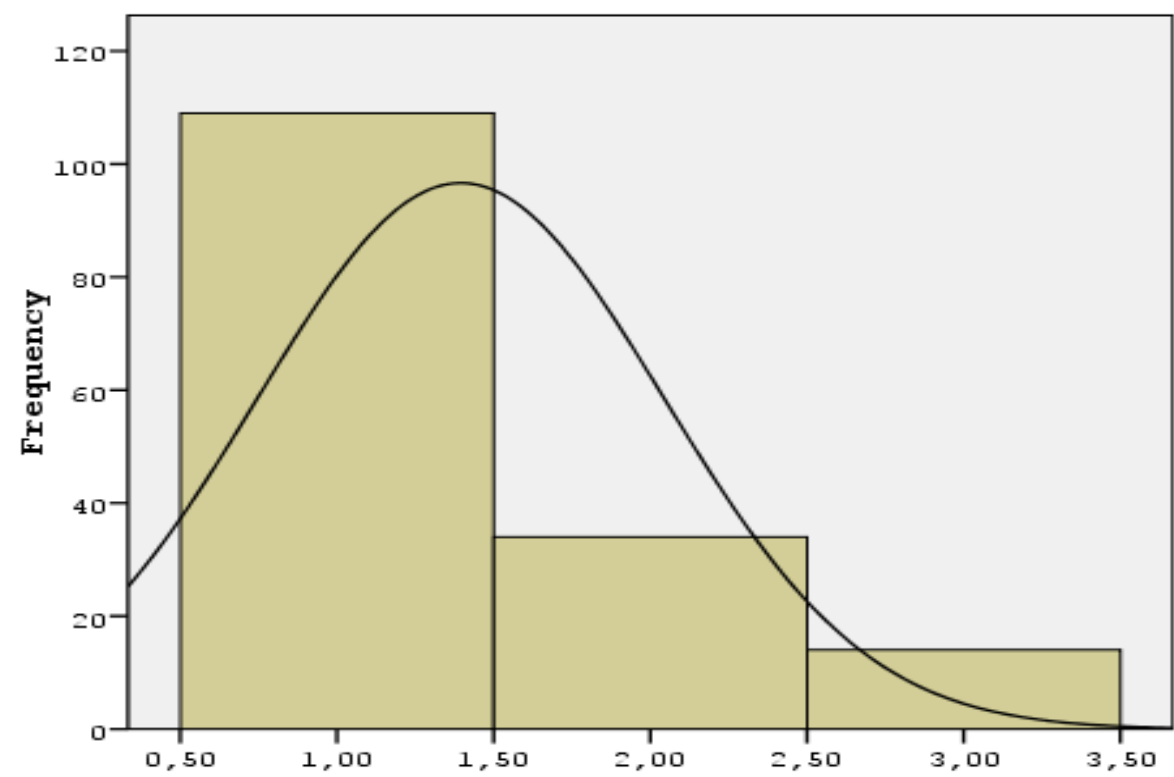

\section{CONCLUSION}

Concerning our research that there is an active and meaningful relation between the strategical financial plannings and the company profitability. It is seen that the profitability is increased as a result of the strategical plannings conducted. Under these circumstances, the growth ratio also increases by increasing the profitability. In parallel with this case that these 
companies reached a growth level above the sector average. The growth of the companies that actualize the financial planning productively becomes easy. Because all the sources obtained are used most efficiently, and more use the resources affects the company growth positively.

It is observed by the analyses done that the strategical financial planning is important for the companies in logistics sector to strengthen their financing structures. The positive relation between the right planning and the right decisions is confirmed as well. Additionally, our research provided to be understood that how important the strategical plannings are. Also, this study reveals that the logistics companies can quickly make their financing structures more competitive due to these plannings. The importance of strategically evaluating of use of financial alternatives is proved and understood that the options used in time affect the economic structure positively. Moreover, it is revealed that the profitability and the company growth move together and both of these variables gain strength by the strategical financial structure.

\section{LIMITEDNESS OF THE RESEARCH}

This research is limited with the perceptions of the managers who take decisions about the effects of the strategical financial planning of the companies in the logistics sector in Turkey on the economic growth. Within this scope, the research must be in a different size and applied in other countries for generalizing so as to include the logistics companies out of Turkey. Moreover, due to this study just includes the decision maker managers, there is also a limitedness belongs to the people. Therefore, the data and findings obtained reflect the experiences, abilities, attitudes and perception levels of the people create the sampling group. It can be thought that due to the similar studies conducted in a bigger universe, we can reach to more important and significant findings.

\section{REFERENCES}

Akın, F. 2015, 'The Definition and the Purpose of the Financial Management,' İstanbul, Beta Printing Inc., p.11

Akın, Ö. and Reyhanoğlu, M. 2014, 'The Innovation Portrait of the Turkey within the Context of the Size of the Companies' (Period of 20022008),"İzmir: Dokuz Eylül University Journal of Social Sciences Institute 16 (1), pp. 23-51.

Aktan, C.C. 1999," New Management Techniques in the 2000s' Strategical Management," İstanbul: TUGIAD Publishing, pp. 1-18.

Dinçer, Ö. 2007, 'Strategical Management and Business Policy,' İstanbul: Alfa Publishing, p.16

Erol, Y., İnce, A. R., Aras, M. 2013," The Choice of Strategical Management Approaches in Turkish Industry: research in companies of ISO 1000," Business and Economics Research Journal, 4 (3), pp.75-92.

Işık, Ö. 2011, “Synergy of Innovation and Strategical Management' Strategical Innovation," Manisa, Celal Bayar University, Journal of Social Sciences 9(2) p.541

Otlu, F. ve Demir, Ö. 2005, "The Cost Systems in Strategical Decisions", Elazığ, Fırat University, Journal of Social Sciences, 15 (1), pp.155170.

Sucu, M. E. 2010, "Strategical Management of SMEs and a Research, A Published Post Graduate Thesis," Denizli: Pamukkale University, University of Social Sciences, p.118

Şener, S. 2009, "Economy Agenda”, Turkish Republic, Çanakkale On Sekiz Mart University Biga Faculty of Economics and Administrative Sciences, Journal of Management Sciences, 7(1), p.27

Uzkurt, C. 2010, "Innovation Management: What is innovation, How it is conducted and marketed?", Publishing of Ankara Chamber of Industry, pp.41-42 